\title{
The effect of dietary inclusion of barley, unmolassed sugar beet pulp and molasses on milk production, digestibility and digesta passage in dairy cows given silage based diet
}

\author{
PEKKA HUHTANEN \\ Department of Animal Husbandry, University of Helsinki \\ SF-00710 Helsinki, Finland
}

\begin{abstract}
Ten dairy cows in early lactation were given five different supplements with grass silage ad libitum according to two $5 \times 5$ Latin square designs. The supplements consisted of barley $(\mathrm{Ba})$, unmolassed sugar beet pulp (SBP) and molasses (Mo) on dry matter (DM) basis as follows: (A) Ba $1000 \mathrm{~g}$, (B) Ba $667 \mathrm{~g}$ and Mo $326 \mathrm{~g}$, (C) Ba $417 \mathrm{~g}$, SBP $410 \mathrm{~g}$ and Mo 163 $\mathrm{g}$, (D) SBP $983 \mathrm{~g}$ and (E) $656 \mathrm{~g} \mathrm{SBP}$ and $326 \mathrm{~g}$ Mo per $\mathrm{kg}$. The lower fat content of SBP and molasses than of Ba was balanced with rapeseed oil. These supplements were fed at the level of $6 \mathrm{~kg} \mathrm{DM} / \mathrm{d}$. In addition, $1 \mathrm{~kg}$ of rapeseed meal was given as a protein supplement.

No differences in silage DM intake between the Ba and SBP supplements were found, but inclusion of a high level of Mo depressed silage and total DM intake. Cows given SBP supplements yielded $1.1 \mathrm{~kg}(\mathrm{P}<0.01)$ more milk and $32 \mathrm{~g}(\mathrm{P}<0.05)$ more protein than those given Ba supplements. Milk fat concentration was lower $(\mathrm{P}<0.001)$ on SBP $(46.0 \mathrm{~g} / \mathrm{kg})$ than on Ba diets $(49.1 \mathrm{~g} / \mathrm{kg}$ ) and thus there was no difference in the yield of fat corrected milk (FCM) and milk fat between the two supplements. Inclusion of $2 \mathrm{~kg}$ of DM of Mo reduced the milk $(\mathrm{P}<0.001), \mathrm{FCM}$, fat and protein yields $(\mathrm{P}<0.01)$ compared to diets without molasses. Supplement $\mathrm{C}$ increased $(\mathrm{P}<0.05)$ the milk yield compared to the other diets but the milk composition was not affected.

The effect of supplements on the digestibility of the ration was determined using acid insoluble ash as a marker. The apparent digestibility of organic matter averaged 0.743 and was not significantly affected by the diet. Digestibility of neutral detergent fibre was higher $(\mathrm{P}<0.001)$ for SBP diets $(0.680)$ than for Ba diets $(0.596)$. Similar differences were observed in the digestibility of other fibre components. However, the digestibility of the silage was not affected by the treatment. Feeding SBP diets resulted in lower $(\mathrm{P}<0.001)$ digestibility of crude protein than did Ba diets. Metabolizable energy (ME) of SBP diets tended to be used more efficiently for milk synthesis than ME of Ba diets. Inclusion of Mo in Ba or SBP did not reduce the efficiency, although the milk yield was decreased.

The passage rate of liquid was determined with CoEDTA and that of particles with $\mathrm{Cr}$-labelled straw. The average mean retention time of liquid ranged from 18.0 to $19.9 \mathrm{~h}$ and that of particles from 36.8 to $37.7 \mathrm{~h}$. Neither time was affected by the treatment. The passage rate of particles from the rumen ranged from 0.045 to 0.048 and that of liquid from 0.096 to 0.104 , irrespective of the diet.
\end{abstract}

Index words: milk production, barley, unmolassed sugar beet pulp, molasses, silage, digestibility, digesta passage 


\section{Introduction}

For high producing dairy cows even the best quality forage fed ad libitum provides insufficient nutrients. To meet the energy and protein requirements, supplementary feeding is needed. Energy supplements are primarily based on cereal grains, and protein supplements on oilseed meal.

Feeding of concentrates with high sugar and starch contents at high levels of supplementation has increased the number of digestive disturbances (De VISSER and De GROOT 1981) and lowered the concentration of milk fat (SUTTON et al. 1985), but only when the supplement comprised a large proportion of the diet. Furthermore, increasing the ratio of grain to forage has changed the energy partition towards body fat deposition (FLATT et al. 1969). Addition of starch to forage based diets leads to a reduction in cellulolytic activity in the rumen (El-SHAZly et al. 1961, MERTENS and LOFTEN 1980). Reduction in the rate and extent of forage digestion, slowing the passage of digesta, will result in decreased forage intake. Replacing starchy supplements by fibrous supplements has widely been reported to increase the digestibility of different fibre components (MAYNE and GORDON 1984, SutTON et al. 1985, THOMAS et al. 1986). FAHMY et al. (1984) reported a smaller decrease in the disappearance of ammoniatreated straw from nylon bags in sheep receiving sugar beet pulp than in sheep receiving barley with increasing levels of supplementation. Similarly, ISTASSE et al. (1986) reported a higher digestibility of ammonia-treated straw in dairy cows on sugar beet pulp based diet than on barley based diet.

At present, sugar beet pulp and wheat bran are the most important fibrous by-products used in the feeding of dairy cows in Finland. In the Finnish feed tables (SALO et al. 1982), it is suggested that $1 \mathrm{~kg}$ of dry matter of sugar beet pulp is equivalent to $0.87-0.90 \mathrm{~kg}$ of dry matter of barley. However, replacing barley with SBP on equal dry matter basis in different forage diets has resulted in similar or slightly better productive value in milk production (CASTLE 1972, CASTLE et al. 1981, MAYNE and Gordon 1984, MurPhy 1985, THOMAS et al. 1986, ISTASSE et al. 1986).

The purpose of the present study was to evaluate the comparative feeding value for milk production of rolled barley, unmolassed sugar beet pulp and molasses when used as supplements with a diet of grass silage ad libitum. In addition, the effects of the supplements on the feed intake, the digestibility of the ration and the passage rate were determined. The effect of the supplements on certain blood metabolites and hormones will be reported later in detail (MIETTINEN and HUHTANEN 1987).

\section{Materials and methods}

\section{Animals and management}

Ten autumn calving Ayrshire cows were used in the experiments. Five of the animals were heifers, and five were cows in their third or fourth lactation. On average, the cows had calved 41 (SE 3) days before the start of the experiment. The average fat corrected milk (FCM) yield of the cows during the previous lactation was 7915 (SE 96) kg. The cows were fed and housed individually. They were fed at 5 and 14 hours and given access to food for $3 \mathrm{~h}$ per feeding time. Refusals were removed and weighed after the morning feeding.

\section{Design and treatments}

The experimental design was two $5 \times 5$ Latin squares, with squares balanced so that every treatment was twice preceded by each of the other treatments. Five different supplements (Table $\downarrow 1)$ were given with a grass silage diet. Energy supplements were given on a flat rate basis of $6 \mathrm{~kg}$ dry matter (DM) daily throughout the experiment. The daily allowance of concentrate was adjusted to supply the same amount of DM. The lower content of ether extract in the unmolassed sugar beet pulp (SBP) and sugarbeet molasses (Mo) than 


\begin{tabular}{lccccc}
\hline & \multicolumn{5}{c}{ Treatment } \\
\cline { 2 - 6 } & A & B & C & D & E \\
\hline Grass silage & ad lib & ad lib & ad lib & ad lib & ad lib \\
Rapeseed meal (kg/d) & 1.0 & 1.0 & 1.0 & 1.0 & 1.0 \\
Concentrate (kg DM) & & & & & - \\
$\quad$ Barley & 6.0 & 4.0 & 2.48 & - & - \\
Beet pulp & - & - & 2.48 & 5.9 & 1.93 \\
Beet molasses & - & 0.04 & 0.98 & - & 0.10 \\
$\quad$ Rapeseed oil & 0.25 & 0.25 & 0.06 & 0.25 & 0.25 \\
Minerals' (kg/d) & & & & & \\
\hline
\end{tabular}

I In mineral mixture (g/kg): Ca 170, P 80, Na 60, Mg 80 .

in barley $(\mathrm{Ba})$ was compensated by the addition of rapeseed oil. Barley was fed in rolled form. The ingredients of the concentrate were weighed separately and mixed before feeding. Direct cut silage was made from secondary growth of timothy, meadow fescue and red clover sward $(45: 35: 20)$. The crops were harvested with a precision chop forage harvester and ensiled with formic acid additive $(5 \mathrm{l} / \mathrm{t})$. Silage was given ad libitum in such a way that refusals accounted for about $10 \%$ of the amount offered.

Each experimental period lasted 21 days. The changes in the diet were made within the first 4 days of the period. Except for live weight and live weight change, the results are based on the data of the third week of the period.

Milk yield was recorded at every milking. Milk samples were taken on days 10,17 and 18 of each period and each set was combined, in proportion to yield, for analyses. The cows were weighed at the beginning of the experiment and on days 6, 7, 20 and 21 of each period. Feed samples were taken weekly and analysed for DM. For other analyses the subsamples of three weeks were pooled.

\section{Digestibility measurements}

Apparent digestibility of the diets was determined in the five older cows using acid insoluble ash (AIA) as a natural marker (VAN KEULEN and YOUNG 1977). Faecal grab sam- ples were taken on 6,14 and 22 hours for 5 days from day 15 onwards. Pooled samples of faeces were dried at $100^{\circ} \mathrm{C}$ for $48 \mathrm{~h}$ and milled to pass through a $1-\mathrm{mm}$ screen.

\section{Digesta passage measurements}

Two markers were used to measure digesta passage in the five older cows: liquid passage was determined with CoEDTA and the passage of particles with Cr-labelled straw. The markers were prepared according to UDÉN $e t$ al. (1980). A single dose of $20 \mathrm{~g}$ of CoEDTA and $100 \mathrm{~g}$ of $\mathrm{Cr}$-straw mixed with concentrate was given on day 15 of each period at the morning feeding. Faecal grab samples were taken at $4(8-36 \mathrm{~h}), 6(36-48 \mathrm{~h})$ and $8 \mathrm{~h}$ (48-112 h) intervals. Samples were dried at $100^{\circ} \mathrm{C}$ for $48 \mathrm{~h}$ and milled to pass through a 1-mm screen.

The rate constants for passage of $\mathrm{Cr}$ were estimated according to the equation of GROWUM and WiLliams (1973), assuming a two pool model:

$$
\begin{array}{ll}
y=A e^{-k_{t}(t-\mathrm{TT})}-A e^{-k_{2}(t-\mathrm{TT})} & \text { for } t>\mathrm{TT} \\
y=0 & \text { for } t<\mathrm{TT}(
\end{array}
$$

where $y$ and $A$ are the marker concentrations in faecal DM, $k_{1}$ and $k_{2}$ are the rate constants associated with the kinetics of the marker in the reticulorumen and hindgut and $t$ is the sampling time (h). TT, transit time (h), is the estimated time for the first appearance of marker in the faeces: 


$$
\mathrm{TT}=\frac{\ln A_{2}-\ln A_{1}}{k_{2}-k_{l}}
$$

where $A_{1}$ and $A_{2}$ are intercept values for the marker concentration in faecal DM and $k_{l}$ and $k_{2}$ are as defined above. Values on the linear declining portion of the line were determined by eye. Because the maximum concentration of Co was found in either the first or second sample after dosing of the marker, it was not possible to estimate $k_{2}$ for the liquid passage rate. Therefore the constant for the passage of liquid was calculated assuming a one-pool model (GROVUM and WiLLiamS 1973):

$$
C=C_{0} e^{-k t}
$$

where $C$ is the concentration of Co in faeces at time $t$ and $C_{0}$ the concentration at time $t_{0}$, and $t$ is the sampling time (h).

Total mean retention time (TMRT) was calculated according to THIELEMANS et al. (1978):

$$
\text { TMRT }=\frac{\sum_{n=1}^{i} t_{i} C_{i} \Delta t_{i}}{\sum_{n=1}^{i} C_{i} \Delta t_{i}}
$$

where $t$ is the time (h) from dosage of the marker to the mid-point of the $i^{\text {th }}$ collection interval, $\mathrm{C}_{\mathrm{i}}$ is the concentration of the marker in the $\mathrm{i}^{\text {th }}$ sample, $\Delta t_{i}$ is the interval between two samplings and $\mathrm{n}$ is the number of faecal samples. TMRT was divided into pool mean retention time (PMRT) and residual mean retention time (RMRT). PMRT was calculated as $1 / k_{l}$ and RMRT as TMRT-PMRT. PMRT was assumed to be the pool effect of rumen and RMRT the effect of caecum and colon. TMRT was also calculated according to Grovum and PhiLlips (1973).

$\mathrm{TMRT}=\mathrm{TT}+1 / k_{1}+1 / k_{2}$

\section{Energy utilization}

The energy requirement for maintenance was calculated from equations of the Agricul- tural Research Council (ARC 1980) and the requirement for live weight change according to the Ministry of Agriculture, Food and Fisheries (MAFF 1975). The gross energy of milk was calculated with the equations of TYRREL and REID (1965). Calculation of digestible organic matter (DOM) intake of cows and heifers was based on the results of the digestibility trial. DOM was converted to digestible energy (DE) assuming an energy content of 19 $\mathrm{MJ} / \mathrm{kg}$ DOM (ARC 1980), and DE was converted to metabolisable energy (ME) using a factor of 0.86 .

\section{Analytical methods}

The DM content of feeds was determined by oven drying at $103^{\circ} \mathrm{C}$ for $24 \mathrm{~h}$. Before analysis the samples were dried in vacuum and milled through a 1-mm screen. Feed analyses were made according to standard procedures. Silage DM content was corrected for volatile losses of lactic acid, volatile fatty acids (VFA) and ammonia as described by PORTER et al. (1984). Ammonia N (McCullough 1967), lactic acid (BARKER and SUMMERSON 1941), sugars (NELSON 1944) and VFA (HUIDA 1973) were analysed and $\mathrm{pH}$ measured of fresh silage samples. Neutral detergent fibre (NDF), acid detergent fibre (ADF) and acid detergent lignin (ADL) were analysed according to GoERING and VAN SoEst (1970), but as modified by Robertson and VAN SOEst (1977) for barley. Starch content was analysed by the method of SALO and SALmi (1968). Net energy in fattening feed units (FFU) and digestible crude protein (DCP) were calculated according to Finnish feed tables (SALO et al. 1982), and ME values according to MAFF (1975). The chemical composition and feed values of the experimental feeds are presented in Table 2.

Milk fat and protein contents were analysed with an infrared milk analyser (IRMA), and the fatty acid composition of milk was determined by gas chromatography.

AIA was determined in feed and faecal samples using $2 \mathrm{~N} \mathrm{HCl}$, as described by $\mathrm{VAN}$ 
Table 2. Chemical composition of experimental feeds $(\mathrm{g} / \mathrm{kg} \mathrm{DM})$ and feed values.

\begin{tabular}{|c|c|c|c|c|c|}
\hline & Silage & Barley & Beet pulp & Molasses & Rapeseed meal \\
\hline Dry matter $(\mathrm{g} / \mathrm{kg})$ & 227 & 867 & 872 & 773 & 878 \\
\hline \multicolumn{6}{|l|}{ In dry matter } \\
\hline Ash & 90 & 27 & 53 & 147 & 77 \\
\hline Crude protein & 174 & 118 & 124 & 148 & 341 \\
\hline Ether extract & 58 & 20 & 8 & nd. & 76 \\
\hline Crude fibre & 311 & 65 & 210 & nd. & 145 \\
\hline $\mathrm{NFE}^{\prime}$ & 367 & 769 & 605 & 705 & 361 \\
\hline NDF & 533 & 213 & 510 & nd. & 270 \\
\hline ADF & 375 & 71 & 266 & nd. & 223 \\
\hline ADL & 31 & 13 & 25 & nd. & 100 \\
\hline Cellulose & 345 & 58 & 241 & nd. & 123 \\
\hline Hemicellulose & 157 & 142 & 243 & nd. & 47 \\
\hline Sugars & 27 & 37 & 86 & 616 & 87 \\
\hline Starch & nd. & 563 & 29 & nd. & 17 \\
\hline \multicolumn{6}{|l|}{ Feed values } \\
\hline $\mathrm{FFU}^{2} / \mathrm{kg} \mathrm{DM}$ & 0.731 & 1.139 & 1.027 & 0.903 & 1.011 \\
\hline $\mathrm{ME} \mathrm{MJ/kg} \mathrm{DM}$ & 10.32 & 13.28 & 11.66 & 12.56 & 11.96 \\
\hline$D_{C P}^{3} \mathrm{~g} / \mathrm{kg} \mathrm{DM}$ & 122 & 86 & 79 & 104 & 285 \\
\hline
\end{tabular}

nd. $=$ not determined, $\mathrm{NFE}=$ nitrogen free extracts, ${ }^{2} \mathrm{FFU}=$ fattening feed unit $=0.7 \mathrm{~kg}$ starch, ${ }^{3} \mathrm{DCP}=$ digestible crude protein.

In silage: $\mathrm{pH} 4.08$; in dry matter $(\mathrm{g} / \mathrm{kg})$ : lactic acid 50 , acetic acid 16 , propionic acid 0.3 , butyric acid 0.2 ; in total nitrogen $(\mathrm{g} / \mathrm{kg})$ : $\mathrm{NH}_{3}-\mathrm{N} \mathrm{46}$, soluble $\mathrm{N} \mathrm{460;} \mathrm{D-value} 0.622$.

Keulen and Young (1977). $\mathrm{Cr}$ and Co were analysed by atomic absorption spectrophotometry after treating the samples as described by WILliams et al. (1962).

\section{Statistical analysis}

Analysis of variance for Latin square experiments was used for digestibility and rate of passage measurements. The model used for statistical analysis was

$y_{i j k l}=T_{i}+C_{j}+P_{k}+e_{i j k l}$,

where $T, C, P$ are treatment, cow and period effects. The model used to analyse the data from the two Latin squares was:

$$
\begin{aligned}
y_{i j k l m}= & S_{i}+C_{j}\left(S_{i}\right)+P_{k}+T_{l}+(S P)_{i k} \\
& +(S T)_{i l}+e_{i j k l m},
\end{aligned}
$$

where $S, C, P$ and $T$ are square, cow, period and treatment effects and $S P$ and $S T$ square $\times$ period and square $\times$ treatment interactions. The treatment effect was further partitioned, using orthogonal contrasts, into effects due to differences between barley and
SBP diets (AB $v$. DE), differences resulting from replacing $\mathrm{Ba}$ or SBP by molasses (AD $v$. BE), or differences between treatment $\mathrm{C} v$. other treatments and interaction between type of supplement (Ba $v$. SBP) and level of molasses (AE $v$. BD).

\section{Results}

\section{Feed intake}

The effect of the treatments on feed intake and nutrient consumption are given in Table 3. Replacing $330 \mathrm{~g} / \mathrm{kg}$ of barley or SBP with molasses on DM basis tended to decrease $(\mathrm{P}=0.065)$ silage DM intake, and the associated difference in total DM intake was significant $(\mathrm{P}<0.05)$. Silage intake was similar on $\mathrm{Ba}$ and SBP diets. However, the interaction between the level of molasses and type of supplement in DM intake, in addition to FFU, $\mathrm{ME}$ and DCP intakes, was significant $(\mathrm{P}<$ 0.05 ). Some cows on treatment $D$ refused small amounts of SBP and the concentrate intake was slightly lower $(\mathrm{P}>0.05)$ for diet $\mathrm{D}$ 
Table 3. Feed intake (kg DM/d) and nutrient consumption in cows given grass silage with different energy supplements.

\begin{tabular}{|c|c|c|c|c|c|c|c|c|c|c|}
\hline & \multicolumn{5}{|c|}{ Treatment } & \multirow{2}{*}{$\begin{array}{l}\text { SEM } \\
24 \mathrm{df}\end{array}$} & \multicolumn{4}{|c|}{$\begin{array}{c}\text { Statistical significance } \\
\text { of effect }\end{array}$} \\
\hline & A & B & $\mathrm{C}$ & D & $\mathrm{E}$ & & $\begin{array}{c}\mathrm{AB} v \\
\mathrm{DE}\end{array}$ & $\begin{array}{c}\mathrm{AD} v \\
\mathrm{BE}\end{array}$ & $\begin{array}{c}\mathrm{AE} v \\
\mathrm{BD}\end{array}$ & $\begin{array}{l}\text { C. } v \text {. } \\
\text { other }\end{array}$ \\
\hline Grass silage & 9.37 & 8.51 & 8.76 & 9.21 & 8.97 & 0.28 & NS & NS & NS & NS \\
\hline Barley & 5.96 & 3.87 & 2.48 & - & - & 0.05 & - & - & - & - \\
\hline Beet pulp & - & - & 2.43 & 5.50 & 3.86 & 0.09 & - & - & - & - \\
\hline Molasses & - & 1.92 & 0.97 & 0.07 & 1.94 & 0.04 & - & - & - & - \\
\hline Rapeseed meal & 0.87 & 0.84 & 0.87 & 0.83 & 0.85 & 0.002 & - & - & - & - \\
\hline Concentrate total & 6.83 & 6.63 & 6.74 & 6.40 & 6.66 & 0.15 & NS & NS & NS & NS \\
\hline Total DM intake & 16.21 & 15.14 & 15.50 & 15.61 & 15.63 & 0.22 & NS & $*$ & $*$ & NS \\
\hline $\begin{array}{c}\text { DM intake as } \% \\
\text { of live weight }\end{array}$ & 3.16 & 2.97 & 3.01 & 3.04 & 3.06 & 0.042 & NS & NS & $*$ & NS \\
\hline DM intake as & & & & & & & & & & \\
\hline $\mathrm{g} / \mathrm{kg} \mathrm{W}^{0.75}$ & 150.4 & 141.0 & 143.1 & 144.5 & 145.2 & 2.27 & NS & NS & $*$ & NS \\
\hline FFU/d & 14.53 & 13.30 & 13.59 & 13.48 & 13.35 & 0.17 & $* *$ & $* * *$ & $* *$ & NS \\
\hline $\mathrm{ME} \mathrm{MJ/d}$ & 186.6 & 174.2 & 175.4 & 171.9 & 174.3 & 2.34 & $* *$ & $*$ & $* *$ & NS \\
\hline DCP g/d & 1899 & 1784 & 1805 & 1807 & 1828 & 30.6 & NS & NS & $*$ & NS \\
\hline
\end{tabular}

$\mathrm{SEM}=$ standard error of means

Significance: NS (non-significant), ${ }^{*}(\mathrm{P}<0.05),{ }^{* *}(\mathrm{P}<0.01),{ }^{* * *}(\mathrm{P}<0.001)$.

Table 4. Daily intake $(\mathrm{kg})$ of crude protein, ether extract, different carbohydrates and crude fibre in cows given grass silage with different energy supplements.

\begin{tabular}{|c|c|c|c|c|c|c|c|c|c|c|}
\hline & \multicolumn{5}{|c|}{ Treatment } & \multirow{2}{*}{$\begin{array}{l}\text { SEM } \\
24 \mathrm{df}\end{array}$} & \multicolumn{4}{|c|}{$\begin{array}{c}\text { Statistical significance } \\
\text { of effect }\end{array}$} \\
\hline & A & B & $\mathrm{C}$ & D & $\mathrm{E}$ & & $\begin{array}{c}\mathrm{AB} v \\
\mathrm{DE}\end{array}$ & $\begin{array}{l}\mathrm{AD} v \\
\mathrm{BE}\end{array}$ & $\begin{array}{l}\mathrm{AE} v \\
\mathrm{BD}\end{array}$ & $\begin{array}{l}\text { C. } v \text {. } \\
\text { other }\end{array}$ \\
\hline Crude protein & 2.63 & 2.50 & 2.55 & 2.58 & 2.61 & 0.04 & NS & NS & NS & NS \\
\hline Ether extract & 0.73 & 0.63 & 0.68 & 0.73 & 0.68 & 0.01 & NS & $* * *$ & NS & NS \\
\hline Starch & 3.37 & 2.19 & 1.48 & 0.17 & 0.13 & 0.03 & $* * *$ & $* * *$ & NS & NS \\
\hline Sugars & 0.55 & 1.65 & 1.21 & 0.85 & 1.85 & 0.03 & $* * *$ & $* * *$ & NS & NS \\
\hline Cellulose & 3.68 & 3.26 & 3.89 & 4.58 & 4.13 & 0.08 & $* * *$ & $* * *$ & NS & NS \\
\hline Hemicellulose & 2.36 & 1.93 & 2.36 & 2.81 & 2.39 & 0.04 & $* * *$ & $* * *$ & NS & NS \\
\hline Crude fibre & 3.42 & 3.02 & 3.53 & 4.10 & 3.72 & 0.07 & $* * *$ & $* * *$ & NS & NS \\
\hline
\end{tabular}

For significance: see Table 3.

than for other treatments. Estimated FFU and $\mathrm{ME}$ intakes were higher $(\mathrm{P}<0.01)$ in cows given $\mathrm{Ba}$ diets than in those given SBP diets. Inclusion of $2 \mathrm{~kg}$ of molasses (on DM basis) in the diet resulted in lower FFU $(\mathrm{P}<0.001)$ and $\mathrm{ME}$ intake $(\mathrm{P}<0.05)$ compared to diets without molasses.

The different carbohydrate composition of concentrate ingredients caused marked differences in the intake of the various carbohydrates (Table 4). Ba and SBP diets differed in composition primarily in terms of the ratio of cell wall carbohydrates to starch. When molasses was included in the Ba diet, sugars were substituted for starch; and in the SBP diet they were substituted for cellulose and hemicellulose.

\section{Milk yield and milk composition}

Dietary inclusion of $2 \mathrm{~kg}$ of molasses reduced significantly $(\mathrm{P}<0.001 ; \mathrm{P}<0.01)$ the milk, FCM, milk fat and protein yields 
Table 5. Milk yield, milk composition and feed conversion in cows given grass silage with different energy supplements.

\begin{tabular}{|c|c|c|c|c|c|c|c|c|c|c|}
\hline & \multicolumn{5}{|c|}{ Treatment } & \multirow{2}{*}{$\begin{array}{l}\text { SEM } \\
24 \mathrm{df}\end{array}$} & \multicolumn{4}{|c|}{$\begin{array}{c}\text { Statistical significance } \\
\text { of effect }\end{array}$} \\
\hline & A & B & C & D & $\mathrm{E}$ & & $\begin{array}{l}\mathrm{AB} v \\
\mathrm{DE}\end{array}$ & $\begin{array}{c}\mathrm{AD} v \\
\mathrm{BE}\end{array}$ & $\begin{array}{c}\mathrm{AE} v \\
\mathrm{BD}\end{array}$ & $\begin{array}{l}\text { C. } v \text {. } \\
\text { other }\end{array}$ \\
\hline Milk yield (kg/d) & 23.3 & 21.9 & 24.0 & 24.4 & 23.0 & 0.37 & $* *$ & $* * *$ & NS & * \\
\hline $\mathrm{FCM}$ yield $(\mathrm{kg} / \mathrm{d})$ & 26.5 & 24.8 & 27.0 & 26.4 & 25.1 & 0.43 & NS & $* *$ & NS & $*$ \\
\hline Fat yield (g/d) & 1146 & 1069 & 1159 & 1109 & 1064 & 20 & NS & $* *$ & NS & $*$ \\
\hline Protein yield $(\mathrm{g} / \mathrm{d})$ & 715 & 682 & 757 & 755 & 706 & 13 & $*$ & $* *$ & NS & $* *$ \\
\hline \multicolumn{11}{|l|}{ Milk composition } \\
\hline Fat $(\mathrm{g} / \mathrm{kg})$ & 49.1 & 49.0 & 48.2 & 45.5 & 46.4 & 0.60 & $* * *$ & NS & NS & NS \\
\hline Protein $(\mathrm{g} / \mathrm{kg})$ & 30.6 & 31.0 & 31.4 & 30.8 & 30.8 & 0.42 & NS & NS & NS & NS \\
\hline \multicolumn{11}{|l|}{ Live weight } \\
\hline Mean $(\mathrm{kg})$ & 512 & 511 & 518 & 514 & 512 & 2.2 & NS & NS & NS & NS \\
\hline Change $(\mathrm{kg} / \mathrm{d})$ & 0.16 & 0.15 & -0.19 & -0.06 & 0.20 & 0.14 & NS & NS & NS & NS \\
\hline \multicolumn{11}{|l|}{ Feed conversion } \\
\hline $\mathrm{FFU} / \mathrm{kg} \mathrm{FCM}^{\prime}$ & 0.383 & 0.358 & 0.366 & 0.359 & 0.351 & 0.013 & NS & NS & NS & NS \\
\hline $\mathrm{kg} \mathrm{DM} / \mathrm{kg} \mathrm{FCM}$ & 0.617 & 0.616 & 0.580 & 0.592 & 0.625 & 0.009 & NS & NS & NS & $* *$ \\
\hline $\mathrm{DCP} \mathrm{g} / \mathrm{kg} \mathrm{FCM}^{2}$ & 60.6 & 59.9 & 55.7 & 56.7 & 60.7 & 1.00 & NS & NS & NS & $* *$ \\
\hline
\end{tabular}

1 Production feed units; intake corrected for maintenance and live weight change

2 Production DCP; intake corrected for maintenance

For significance: see Table 3.

(Table 5). The effect of molasses on production was similar, whether included in the $\mathrm{Ba}$ or SBP diet. But cows given SBP supplements yielded $1.1 \mathrm{~kg}(\mathrm{P}<0.01)$ more milk and $32 \mathrm{~g}$ $(\mathrm{P}<0.05)$ more protein on average than those given $\mathrm{Ba}$ supplements. The more complex mixture of concentrate (treatment $\mathrm{C}$ ) produced more milk, FCM, milk fat $(\mathrm{P}<0.05)$ and milk protein $(\mathrm{P}<0.01)$ than the other diets. Treatment effects on milk, FCM, fat and protein production were similar in heifers and older cows; $P$ for square $\times$ treatment interaction was $0.91,0.33,0.76$ and 0.57 , respectively. The protein concentration in the milk was not affected by the diet, but SBP supplements decreased fat concentration in the milk significantly $(\mathrm{P}<0.001)$ compared to Ba supplements.

In cows given diets $\mathrm{C}$ and $\mathrm{D}$ the live weight change was negative, while for those given other diets it was positive, but the differences were not statistically significant.

Feed conversion, expressed in terms of production feed units per $\mathrm{kg}$ FCM, tended to be slightly better on SBP diets than on Ba. In terms of DM/ kg FCM, there were no differences between $\mathrm{Ba}$ and SBP diets. On supple- ment $\mathrm{C}$, significantly less $(\mathrm{P}<0.01) \mathrm{DM}$ and DCP were consumed per $\mathrm{kg}$ of FCM compared to the other treatments.

The fatty acid composition of milk is shown in Table 6, with the individual fatty acids grouped according to their origin. Concentration of butyric acid $\left(\mathrm{C}_{4: 0}\right)$ was lower $(\mathrm{P}<0.01)$ on SBP diets than on Ba diets. Short-chain fatty acids $\left(\mathrm{C}_{6: 0}\right.$ to $\left.\mathrm{C}_{14: 1}\right)$ synthesized de novo in the udder were not affected by the type of supplement. There were no differences in the proportions of $\mathrm{C}_{18: 0}$ and $\mathrm{C}_{18: 1 \text {, }}$ which are entirely derived from blood. The difference between the $\mathrm{Ba}$ and SBP diets in the proportion of linolic acid $\left(\mathrm{C}_{18: 2}\right)$, although significant, was small. The proportion of C-16 acids, which arise partly from blood, was higher $(\mathrm{P}<0.01)$ on $\mathrm{Ba}$ than on SBP diets. Compared to the $\mathrm{Ba}$ diets the SBP diets increased significantly $(\mathrm{P}<0.01)$ the proportion of fatty acids with odd number of carbon. This was mainly due to the difference of $0.30 \%$-unit $(\mathrm{P}<0.001)$ in the proportion of $\mathrm{C}_{15}$ acid between $\mathrm{Ba}$ and SBP diets. Inclusion of molasses in the diet reduced $(\mathrm{P}<0.05)$ the proportion of fatty acids with odd number of carbon. 
Table 6. Fatty acid composition ( $\%$ by weight) of milk fat of cows given grass silage with different energy supplements.

\begin{tabular}{|c|c|c|c|c|c|c|c|c|c|c|}
\hline \multirow{2}{*}{ Fatty acid } & \multicolumn{5}{|c|}{ Treatment } & \multirow{2}{*}{$\begin{array}{l}\text { SEM } \\
24 \mathrm{df}\end{array}$} & \multicolumn{4}{|c|}{$\begin{array}{c}\text { Statistical significance } \\
\text { of effect }\end{array}$} \\
\hline & A & B & $\mathrm{C}$ & D & $\mathrm{E}$ & & $\begin{array}{l}\mathrm{AB} v \\
\mathrm{DE}\end{array}$ & $\begin{array}{l}\mathrm{AD} v \\
\mathrm{BE}\end{array}$ & $\begin{array}{l}\mathrm{AE} v \\
\mathrm{BD}\end{array}$ & $\begin{array}{l}\text { C. } v \text {. } \\
\text { other }\end{array}$ \\
\hline $4: 0$ & 3.65 & 3.60 & 3.60 & 3.34 & 3.47 & 0.07 & $* *$ & NS & NS & NS \\
\hline $6: 0$ to $14: 1$ & 24.2 & 24.1 & 23.8 & 24.6 & 23.4 & 0.73 & NS & NS & NS & NS \\
\hline $16: 0$ to $16: 1$ & 35.2 & 34.9 & 34.4 & 32.8 & 33.2 & 0.64 & $* *$ & NS & NS & NS \\
\hline $18: 0$ & 10.2 & 10.6 & 10.7 & 10.7 & 10.8 & 0.25 & NS & NS & NS & NS \\
\hline $18: 1$ & 19.7 & 20.0 & 20.3 & 20.6 & 22.0 & 0.96 & NS & NS & NS & NS \\
\hline $18: 2$ & 2.36 & 2.32 & 2.39 & 2.59 & 2.46 & 0.06 & $* *$ & NS & NS & NS \\
\hline $18: 3$ & 0.58 & 0.63 & 0.64 & 0.65 & 0.67 & 0.03 & NS & NS & NS & NS \\
\hline $\begin{array}{l}\text { All unsaturated } \\
\text { fatty acids }\end{array}$ & 26.0 & 26.4 & 26.4 & 27.1 & 28.7 & 1.10 & NS & NS & NS & NS \\
\hline Fatty acids with & & & & & & & & & & \\
\hline odd number of $\mathrm{C}$ & 3.54 & 3.42 & 3.45 & 3.98 & 3.66 & 0.10 & $* *$ & $*$ & NS & NS \\
\hline
\end{tabular}

For significance: see Table 3 .

Table 7. Mean chemical composition $(\mathrm{g} / \mathrm{kg} \mathrm{DM})$ of experimental diets and feed intake in digestibility trial.

\begin{tabular}{|c|c|c|c|c|c|c|c|}
\hline & \multicolumn{5}{|c|}{ Treatment } & \multirow{2}{*}{$\begin{array}{l}\text { SEM } \\
12 \mathrm{df}\end{array}$} & \multirow{2}{*}{$\begin{array}{c}\text { Signifi- } \\
\text { cance }\end{array}$} \\
\hline & A & B & $\mathrm{C}$ & D & $\mathrm{E}$ & & \\
\hline Ash & 78 & 93 & 89 & 89 & 99 & 0.44 & $* * *$ \\
\hline Crude protein & 161 & 163 & 162 & 163 & 164 & 1.09 & NS \\
\hline Crude fibre & 214 & 205 & 228 & 259 & 238 & 2.54 & $* * *$ \\
\hline Ether extract & 45 & 42 & 44 & 46 & 43 & 0.55 & $* *$ \\
\hline NFE & 502 & 495 & 476 & 444 & 453 & 4.08 & $* * *$ \\
\hline NDF & 406 & 378 & 431 & 498 & 445 & 3.47 & $* * *$ \\
\hline ADF & 261 & 250 & 281 & 321 & 294 & 2.88 & $* * *$ \\
\hline ADL & 28 & 26 & 29 & 32 & 29 & 0.10 & $* * *$ \\
\hline Cellulose & 234 & 224 & 252 & 290 & 266 & 2.88 & $* * *$ \\
\hline Hemicellulose & 145 & 128 & 150 & 176 & 151 & 1.35 & $* * *$ \\
\hline DM intake $\mathrm{kg} / \mathrm{d}$ & 17.40 & 15.88 & 16.40 & 16.47 & 16.35 & 0.35 & NS \\
\hline
\end{tabular}

For significance: see Table 3 .

\section{Digestibility}

Table 7 gives the chemical composition of the experimental diets of the cows during digestibility measurements. All the differences between the diets were significant except the concentration of crude protein. The main differences between the $\mathrm{Ba}$ and SBP diets were a higher concentration of soluble residues (OM - crude protein - ether extract NDF) (320 v. $228 \mathrm{~g} / \mathrm{kg} \mathrm{DM})$ and a lower concentration of fibre components in the Ba diets.

There were no significant differences between the treatments in digestibility of OM (Table 8). However, there was a trend for higher OM digestibility with the diets containing molasses. Crude protein digestibility was significantly $(\mathrm{P}<0.001)$ lower in cows offered SBP than in those offered Ba supplements. Replacement of Ba by SBP increased the digestibility of crude fibre $(\mathrm{P}<0.01)$, $\mathrm{NDF}, \mathrm{ADF}$, cellulose and hemicellulose $(\mathrm{P}<$ $0.001)$. Replacing $330 \mathrm{~g} / \mathrm{kg}$ of barley or SBP by Mo improved $(\mathrm{P}<0.05)$ the digestibility of DM and nitrogen-free extracts (NFE). The digestibility of the various fibre components was not affected by inclusion of Mo in the diet. The effect of molasses on the digestibility of dietary constituents was the same whether given with barley or SBP. Digestibility of 
Table 8. Digestibility of different dietary constituents in cows given grass silage with different energy supplements.

\begin{tabular}{|c|c|c|c|c|c|c|c|c|c|c|}
\hline & \multicolumn{5}{|c|}{ Treatment } & \multirow{2}{*}{$\begin{array}{l}\text { SEM } \\
24 \mathrm{df}\end{array}$} & \multicolumn{4}{|c|}{$\begin{array}{c}\text { Statistical significance } \\
\text { of effect }\end{array}$} \\
\hline & A & B & $\mathrm{C}$ & D & $\mathrm{E}$ & & $\begin{array}{c}\mathrm{AB} v \\
\mathrm{DE}\end{array}$ & $\begin{array}{c}\mathrm{AD} v \\
\mathrm{BE}\end{array}$ & $\begin{array}{c}\mathrm{AE} v . \\
\mathrm{BD}\end{array}$ & $\begin{array}{l}\text { C. } v \text {. } \\
\text { other }\end{array}$ \\
\hline Dry matter & 0.720 & 0.739 & 0.730 & 0.707 & 0.724 & 0.0062 & $*$ & $*$ & NS & NS \\
\hline Organic matter & 0.740 & 0.755 & 0.750 & 0.730 & 0.741 & 0.0061 & NS & NS & NS & NS \\
\hline Crude protein & 0.728 & 0.738 & 0.725 & 0.691 & 0.697 & 0.0085 & $* * *$ & NS & NS & NS \\
\hline Ether extract & 0.735 & 0.769 & 0.760 & 0.738 & 0.726 & 0.0092 & NS & NS & NS & NS \\
\hline Crude fibre & 0.623 & 0.640 & 0.667 & 0.684 & 0.682 & 0.0121 & $* *$ & NS & NS & NS \\
\hline NFE & 0.794 & 0.805 & 0.796 & 0.769 & 0.788 & 0.0066 & $* *$ & $*$ & NS & NS \\
\hline NDF & 0.600 & 0.592 & 0.653 & 0.682 & 0.677 & 0.0119 & $* * *$ & NS & NS & NS \\
\hline ADF & 0.555 & 0.551 & 0.592 & 0.620 & 0.622 & 0.0136 & $* * *$ & NS & NS & NS \\
\hline Cellulose & 0.664 & 0.674 & 0.705 & 0.722 & 0.725 & 0.0103 & $* * *$ & NS & NS & NS \\
\hline Hemicellulose & 0.680 & 0.670 & 0.762 & 0.794 & 0.782 & 0.0135 & $* * *$ & NS & NS & NS \\
\hline
\end{tabular}

For significance: see Table 3.

Table 9. Calculated energy balance (MJ/day) and efficiency of conversion of ME surplus to maintenance into milk in cows given grass silage and different energy supplements.

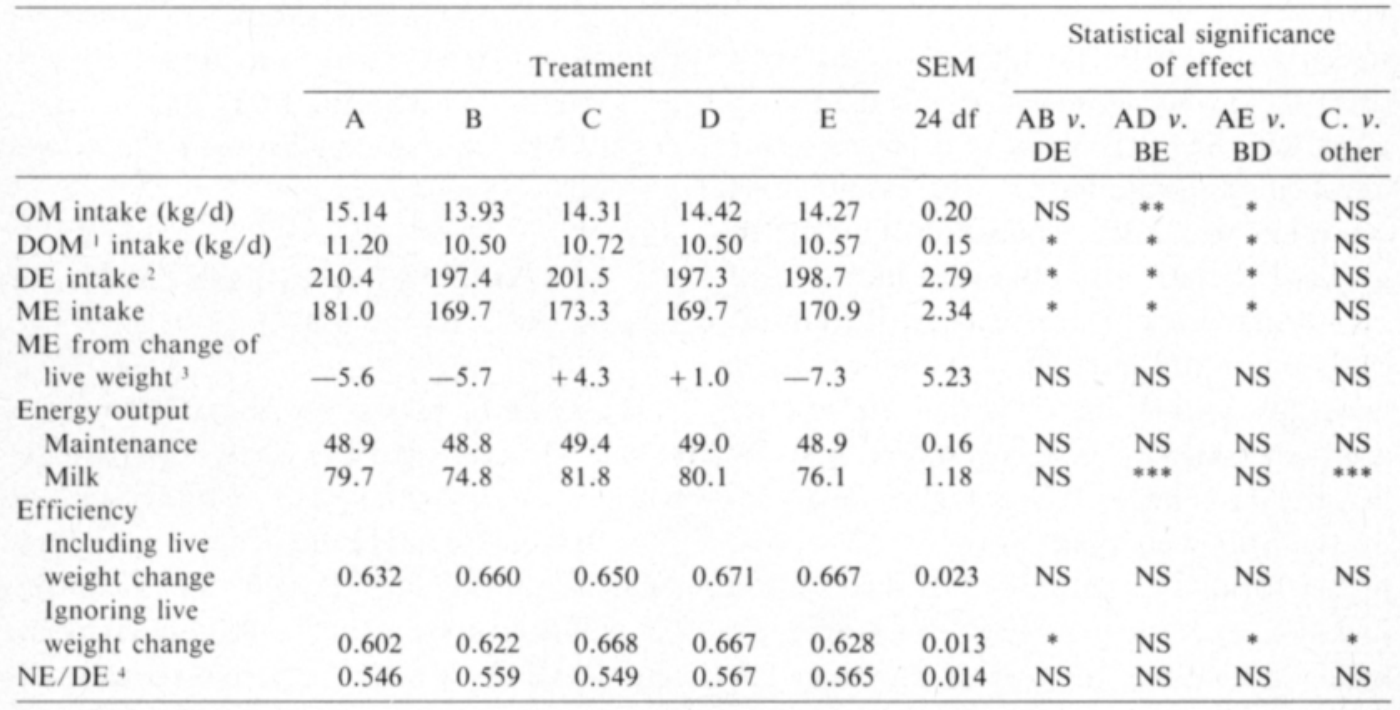

1 $\mathrm{DOM}=$ digestible organic matter; ${ }^{2} \mathrm{DE}=$ digestible energy

3 Allowing $28 \mathrm{MJ}$ for each $\mathrm{kg}$ lost and subtracting $34 \mathrm{MJ}$ for each $\mathrm{kg}$ gained

$+\mathrm{NE}=$ net energy for milk, live weight gain $(20 \mathrm{MJ} / \mathrm{kg})$ and maintenance $\left(0.3 \mathrm{MJ} / \mathrm{kg} \mathrm{W} \mathrm{W}^{0.75}\right)$

For significance: see Table 3

silage OM and crude fibre, calculated as a difference using the digestibility coefficients of SALO et al. (1982) for concentrates, was not affected by the treatment. The average digestibilities of silage OM for treatments $\mathrm{A}-\mathrm{E}$ were $0.671,0.679,0.686,0.669$ and 0.671 (SEM 0.011) and those of crude fibre 0.673, $0.681,0.687,0.675$ and 0.680 (SEM 0.015), respectively.

\section{Energy balance}

Dietary inclusion of $2 \mathrm{~kg}$ of molasses reduced $\mathrm{OM}$ intake significantly $(\mathrm{P}<0.01)$ (Table 9). Digestible organic matter (DOM), $\mathrm{DE}$ and $\mathrm{ME}$ intakes were lower $(\mathrm{P}<0.05)$ on SBP than on $\mathrm{Ba}$ diets and lower $(\mathrm{P}<0.05)$ on diets containing $2 \mathrm{~kg}$ of molasses than on diets without molasses. The effect of molas- 
Table 10. Total mean retention time (TMRT), pool mean retention time (PMRT), residual mean retention time $(\mathrm{RMRT})$, transit time (TT) and rate of passage $\left(k_{1}\right.$ and $\left.k_{2}\right)$ of $\mathrm{Cr}$-labelled straw and CoEDTA in cows fed on grass silage with different energy supplements.

\begin{tabular}{|c|c|c|c|c|c|c|c|c|c|}
\hline & \multicolumn{5}{|c|}{ Treatment } & \multirow{2}{*}{$\begin{array}{l}\text { SEM } \\
12 \mathrm{df}\end{array}$} & \multicolumn{3}{|c|}{ Significance } \\
\hline & A & B & $\mathrm{C}$ & D & $\mathrm{E}$ & & Cow & Period & Treatm. \\
\hline TMRT $^{1} \mathrm{Cr}(\mathrm{h})$ & 37.7 & 37.3 & 37.1 & 36.8 & 37.7 & 0.82 & $* * *$ & $* * *$ & NS \\
\hline PMRT Cr (h) & 22.5 & 21.6 & 22.1 & 22.5 & 22.5 & 0.85 & NS & $* * *$ & NS \\
\hline RMRT Cr (h) & 15.3 & 15.7 & 15.0 & 14.2 & 15.2 & 0.89 & $* *$ & NS & NS \\
\hline TT $\quad \mathrm{Cr}(\mathrm{h})$ & 9.5 & 9.6 & 8.5 & 9.3 & 9.4 & 0.50 & $*$ & NS & NS \\
\hline $\mathrm{TMRT}^{2} \mathrm{Cr}(\mathrm{h})$ & 37.5 & 37.3 & 36.8 & 37.2 & 37.9 & 0.80 & $* * *$ & $* * *$ & NS \\
\hline $\mathrm{Cr}$ & 0.047 & 0.048 & 0.047 & 0.045 & 0.046 & 0.002 & NS & $* * *$ & NS \\
\hline $\mathrm{Cr}$ & 0.215 & 0.188 & 0.188 & 0.215 & 0.196 & 0.021 & $* *$ & $* * *$ & NS \\
\hline TMRT Co (h) & 19.9 & 19.6 & 18.3 & 18.3 & 18.0 & 0.66 & $* *$ & $*$ & NS \\
\hline PMRT Co (h) & 11.0 & 9.7 & 9.8 & 9.7 & 10.3 & 0.47 & $*$ & $* * *$ & NS \\
\hline RMRT Co (h) & 9.0 & 9.8 & 8.5 & 8.6 & 9.2 & 0.43 & $* *$ & $* * *$ & NS \\
\hline$k_{\text {I }} \quad \mathrm{Co}$ & 0.096 & 0.108 & 0.104 & 0.105 & 0.099 & 0.004 & $*$ & $* * *$ & NS \\
\hline
\end{tabular}

1 Calculated according to Tielemans et al. (1978);

2 Calculated according to Grovum and Phill.tps (1973); For significance see Table 3.

ses on estimated DOM intake was different $(\mathrm{P}<0.05)$ when given with barley than when given with SBP; there was a decrease of 0.7 $\mathrm{kg}$ when given with barley, whereas no effect was found with SBP. Production of milk energy was lower $(\mathrm{P}<0.001)$ with inclusion of $2 \mathrm{~kg}$ of molasses. The efficiency of transferring surplus ME into milk $\left(k_{l 0}\right)$ averaged 0.656 when live weight change was included, and was not affected by the energy source. Ignoring live weight change, $k_{l}$, was higher $(\mathrm{P}<0.05)$ on the SBP diets than on the Ba diets, and higher for diet $\mathrm{C}$ than the other diets. When included in barley, molasses improved $k_{l}$, while on SBP diet the reverse was true. The interaction was significant $(\mathrm{P}<0.05)$ when live weight change was ignored.

\section{Digesta passage}

No significant treatment effect was found on the measurements of retention time or passage rate of particle or liquid phase of the digesta (Table 10). On the other hand, most of the cow and period effects on digesta passage parameters were significant. Estimates for TMRT of Cr-straw were similar, irrespective of the calculation method: the value for TMRT was 37.3 (SE 0.35) when calculated ac- cording to GrovUM and PHILLIPS (1973) and 37.3 (SE 0.35) according to THIELEMANS $e t$ al. (1978). The relation between these two methods was:

$$
\begin{aligned}
\mathrm{y}= & -1.2(\mathrm{SE} 1.8)+1.03(\mathrm{SE} 0.047) \\
& \times(\operatorname{RSD} 1.14 ; r 0.977)
\end{aligned}
$$

Higher DM intake as per cent of live weight (Table 11) decreased the TMRT of particle marker $(P<0.001)$ and liquid marker $(\mathrm{P}<0.05)$. DM intake did not affect the pool mean retention time (PMRT) significantly, but at higher levels of intake the residual mean retention times (RMRT) of particles and liquid were decreased $(\mathrm{P}<0.001 ; \mathrm{P}<0.01)$.

Table 11. The regression on digesta retention (h) on DM intake ( $\%$ of live weight).

\begin{tabular}{lcccc}
\hline $\begin{array}{l}\text { Param- } \\
\text { eter }\end{array}$ & $\begin{array}{c}\text { Intercept } \\
\text { (SE) }\end{array}$ & $\begin{array}{c}\text { Slope } \\
\text { (SE) }\end{array}$ & $\begin{array}{c}\text { Signifi- } \\
\text { cance }\end{array}$ & RSD \\
\hline TMRT $_{\mathrm{Cr}}$ & $58.9(4.5)$ & $-7.00(1.43)$ & $* * *$ & 2.38 \\
PMRT $_{\mathrm{Cr}}$ & $24.2(3.2)$ & $-0.63(1.04)$ & NS & 1.71 \\
RMRT $_{\mathrm{Cr}}$ & $34.8(3.5)$ & $-6.37(1.13)$ & $* * *$ & 1.86 \\
TMRT $_{\mathrm{Co}}$ & $28.8(4.2)$ & $-3.14(1.29)$ & $*$ & 2.15 \\
PMRT $_{\mathrm{Co}}$ & $11.9(2.5)$ & $-0.59(0.80)$ & NS & 1.32 \\
RMRT $_{\mathrm{Co}}$ & $16.9(2.2)$ & $-2.56(0.71)$ & $* *$ & 1.07 \\
\hline
\end{tabular}

$\mathrm{SE}=$ standard error;

RSD $=$ residual standard deviation 


\section{Discussion}

The silage given to the cows was well preserved with low $\mathrm{pH}$ and low concentration of fermentation acids, with 0.76 of the fermentation acids being lactic acid. The extent of proteolysis was small with low proportions of ammonia and soluble $\mathrm{N}$ in total $\mathrm{N}$.

\section{Feed intake}

There was no difference in silage DM intake between the Ba and SBP supplements, in agreement with the results of CASTLE et al. (1981). They reported decreases in the intake of silage DM of 0.44 and $0.40 \mathrm{~kg}$ respectively, when feeding $1 \mathrm{~kg}$ of $\mathrm{Ba}$ or SBP. On the other hand, THOMAs et al. (1986) recorded a significant increase of $0.9 \mathrm{~kg}$ in silage DM intake when Ba supplement was replaced by a mixture of unmolassed beet pulp $(555 \mathrm{~g} / \mathrm{kg})$ and rice bran $(314 \mathrm{~g} / \mathrm{kg})$. In view of the similar substitution rate they suggested that the increase in forage intake was not mediated solely by changes in fibre digestion in the rumen. CHAMBERlain et al. (1984) found a different response in silage intake when they modifyed the composition of supplement, and their data indicate that higher intakes with SBP can be expected only with highly digestible silage and high concentration of total N. In contrast to this, MAYNE and GORDON (1984) reported with highly digestible silage (D-value 0.691) a significantly lower silage DM intake on SBP than on $\mathrm{Ba}$. In the present study the D-value of silage was 0.622 , similarly to the studies of CASTle et al. (1981) and ThOMAS et al. (1986). ISTASSE et al. (1986) found a tendency for lower feed intake on SBP than on $\mathrm{Ba}$ supplements on diets based on $\mathrm{NH}_{3}$-treated straw.

Under other circumstances, in grazing cattle (MEIJS 1986) or with high levels of concentrate in hay based diets (SUTTON et al. 1984), forage intakes has been higher in cows given concentrates based on fibrous by-products than in those given starchy concentrates. A possible explanation of the increased forage intake is given by STEG et al. (1985). High levels of easily fermentable carbohydrates in starchy concentrates tend to decrease rumen $\mathrm{pH}$ and increase VFA concentration in the rumen, resulting in a lower cellulolytic activity. However, in the present study, the supplements comprised ca. 0.43 of total DM, and on that level of supplementation to cows given silage based diets MURPHY et al. (1986) observed no differences in rumen $\mathrm{pH}$ between barley and barley-sugar beet pulp (1:2) supplements. Similarly, there were no differences in the rate of disappearance of silage or hay DM from nylon bags, and rumen $\mathrm{pH}$ did not differ in bulls given diets of silage supplemented with barley or SBP at the level of 0.52 of the total DM intake (HUHTANEN 1987).

The effect of dietary inclusion of molasses on silage DM intake cannot be explained solely by physical regulation. Voluntary intake of rations rich in forages is generally restricted by the capacity of the reticulorumen. Disappearance of digesta from the rumen occurs either by microbial degradation and absorption of end products or by passage of undigested residues to the lower digestive tract (STEG et al. 1985). However, in the present study, molasses had no effect either on the digestibility of different cell wall components or on the retention time of Cr-labelled straw particles. The degradation rate of forages in the rumen was similar in bulls when $330 \mathrm{~g} / \mathrm{kg}$ of Ba was replaced by Mo (HUHTANEN 1987). Possibly the lower forage intake on Mo diets is due to metabolic control. In the case of molasses containing diet, the higher fermentation rate of sugars than that of starch or fibre (SUTTON 1980) may increase the concentrations of ruminal acetate, duodenal lactate and hepatic uptake of propionate, which are feedback signals for termination of feeding (FORBES 1980). Because the access to feed was limited to $3 \mathrm{~h}$ per feeding time, early termination of the meal may have reduced forage intake in cows given Mo diets.

\section{Production response}

Cows given SBP yielded more milk than those given $\mathrm{Ba}$ either with or without molas- 
ses. A similar increase in milk yield was also recorded by THOMAS et al. (1986) when $\mathrm{Ba}$ supplement was replaced by a mixture of SBP, extracted rice bran and fat prills. However, MAYNE and GORDON (1984) found no change in milk yield with $\mathrm{Ba}$ and SBP used at two levels of supplementation with ad libitum silage and ISTASSE et al. (1986) found a tendency for higher milk yield on Ba based diet than on SBP based diet. In earlier experiments (BHATTACHARYA and SleimAN 1971, BHATTACHRYA and LUBBADAH 1971, CASTLE 1972, CASTLE et al. 1981) there were no statistically significant differences in milk production between $\mathrm{Ba}$ and SBP supplements, although in most studies the milk yield was slightly higher when SBP diets were given. In grazing cows the milk yield was higher when $\mathrm{Ba}$ was replaced by SBP (MURPHY 1985), or more generally, starchy concentrate by fibrous concentrate (MEIJS 1986). The experimental design of the present study does not allow assesment of the residual effects of the diets, but THOMAS et al. (1986) found in mid lactation a large positive residual effect of $+1.6 \mathrm{~kg}$ per day of substitution of $\mathrm{Ba}$ with SBP based supplement.

Milk fat content was lower in cows given SBP supplements than in those given $\mathrm{Ba}$. The linear trend of the level of SBP $(\mathrm{kg} \mathrm{DM} / \mathrm{d})$ explained $94 \%$ of the sum of squares of the treatment effect. This is in agreement with the observation of THOMAS et al. (1986) of a markedly higher fat content in cows given $\mathrm{Ba}$ supplement at a level of supplement similar to the present study (ca. 0.44). Similarly, CASTle and WATSON (1975) found a lower milk fat content when barley was replaced by dried grass as a supplement to silage, despite a higher forage intake and fibre content in the dried grass diet. On the other hand, at a level of ca. 0.4 of the total DM intake, CASTLE et al. (1981) noticed no differences in milk fat content between $\mathrm{Ba}$ and SBP supplements.

Only small differences were found at the higher level of supplement (0.65) in milk fat content (THOMAS et al. 1986). Likewise, MAYNE and Gordon (1984) and SutTON et al. (1985) observed little effect of the type of supplement on milk fat when the supplement comprised 0.5 to 0.6 of the total DM. However, marked reductions in milk fat content and fat yield were noted when starch based concentrate was fed at the level of 0.8 of total DM (SUTTON et al. 1985) or SBP replaced by flaked maize (LEES et al. 1982).

In the present study, the reduced milk fat content on SBP diets cannot be explained by the proportion of forage in the diet or by dietary fibre content, which exceeded the minimum recommended value of $18 \%$ of crude fibre (KAUFMANN 1976) or $22 \%$ of ADF (SUTTON 1984), and was higher on SBP diets.

According to SuTTON (1984), changes in the rumen VFA proportions account for about two thirds of the variation in milk fat content and, on average, there is a fall in milk fat content of approximately $5 \mathrm{~g} / \mathrm{kg}$ for every unit fall in the ratio acetate plus butyrate to propionate. Rumen VFA was not measured in the present study, but MURPHY et al. (1986) found a decrease in this ratio from 5.2 to 4.5 in dairy cows when $670 \mathrm{~g} / \mathrm{kg}$ of $\mathrm{Ba}$ was replaced by SBP. The results of CASTLE (1972) indicate a similar trend, and Castle noted as well a lower fat content on SBP diet than on $\mathrm{Ba}$ diet. In these studies, the major changes in rumen VFA proportions included an increase in propionate and a decrease in butyrate on SBP diets. When different VFAs were infused into the rumen, propionate had a negative effect and butyrate a highly positive effect on milk fat content (THOMAS and CHAMBERLAIN 1984). In the present study VFA theory finds support in the trend toward a lower concentration of $\beta$-hydroxybutyrate in blood plasma (MIETTINEN and HUHTANEN 1987) and in the lower proportion of butyric acid in milk fat in cows given SBP supplements. In grazing cows, on the other hand, the proportion of butyrate tended to be higher and that of propionate lower when barley was replaced by molassed SBP (MURPHY 1985).

In silage diets, inclusion of cereals has been found to reduce the proportion of acetate and increase the proportion of butyrate, and pro- 
duce only small changes in the proportion of propionate (THOMAS et al. 1980). This may explain the high concentration of milk fat when barley diets were given.

A significantly higher protein yield on the SBP diet than on the Ba diet has not been reported earlier, but a similar trend has been observed by CASTLE et al. (1981), THOMAS et al. (1986) and ISTASSE et al. (1986). In the present study, the increase in protein yield with SBP supplements was accompanied by an increase in milk yield without any change in protein contents. The similar protein content with barley and SBP diets is in agreement with the findings of CASTLE (1972), CASTLE et al. (1981) and MAYNE and GORDON (1984). The findings of THOMAS et al. (1986) of a lower concentration of milk protein with SBP supplement may have been due to the inclusion of fat in their SBP diet. Two suggestions can be offered for higher protein yield with SBP. First, the proportion of protein of SBP degraded in the rumen has been reported to be lower than that of barley (MAYNE and GORDON 1984, MADSEN and HVELPLUND 1986). The effect of increased flow of dietary protein depends, however, on the balance between the protein supply and requirement. Second, of the individual end proaucts of digestion, acetate and propionate increased and butyrate decreased the milk protein yield in the infusion studies reviewed by (THOMAS and CHAMBerlain 1984). Thus, a high proportion of butyrate in rumen VFA on silage diets supplemented with cereals (THOMAS et. al. 1980) may explain the lower protein yield on $\mathrm{Ba}$ diets.

Inclusion of $2 \mathrm{~kg}$ of molasses in Ba and SBP caused a significant and similar reduction in milk yield $(1.4 \mathrm{~kg})$ without any change in milk composition. In the case of $\mathrm{Ba}$ diet, the decreased production can probably be attributed to the lower silage intake with Mo. The reduction in milk yield on SBP diet is in agreement with recent observations of PARKINS et al. (1986) and HEMINGWAY et al. (1986) who found that the inclusion of molasses in SBP in silage based diets generally enhances the content of milk fat, but reduced milk yield. In the present study, the slightly lower silage intake is insufficient to explain the reduced milk yield in cows given SBP and molasses. Rather the tendency for higher live weight gain when molasses was included in SBP suggests a change in nutrient partition towards body tissues.

Lower efficiency of utilization of large amounts of soluble sugars has been reported by BROSTER et al. (1970) who compared 2.7 $\mathrm{kg}$ of sucrose and $3.2 \mathrm{~kg}$ of glucose with equal amounts of digestible energy of concentrate, by LOFGREEN and OTAGAKI (1960) who added $2 \mathrm{~kg}$ of molasses and by BOWMAN and HUBER (1967) who used $3.5 \mathrm{~kg}$ of lactose. A comparison of fodder beet with $\mathrm{Ba}$ showed beet to maintain higher fat content than $\mathrm{Ba}$ but to result in lower yields, so that fat yield was the same (KROHN and ANDERSEN 1980).

The increase in milk, FCM, milk fat and protein yields in response to feeding the more complex supplement (treatment C) can partly be explained by the negative effect of high levels of Mo in the diet. However, supplement $\mathrm{C}$ also produced a small positive effect of $+0.5 \mathrm{~kg}$ of FCM, + $31 \mathrm{~g}$ of milk fat and + $22 \mathrm{~g}$ of milk protein per day compared to the mean values for $\mathrm{Ba}$ and SBP given without Mo. The live weight loss in cows given supplement $\mathrm{C}$ tended to be greater, suggesting an increase in the amount of energy withdrawn from body tissues. The slightly higher concentration of acetoacetate in cows given supplement C (MIETTINEN and HuHTANEN 1987) also suggests increased mobilization of body fat. Energy balance experiments have shown that the productive value of a mixed diet is in many instances greater than the arithmetic mean of the ingredient feedstuffs (MOE et al. 1972). Although the full explanation of this associative effect is not clearly understood, it is likely that at least a portion of the effect is due to nutritional imbalance of one or both ration components when fed alone. In the present study, the associative effect of $\mathrm{Ba}$ and SBP and the effect of a lower level of Mo are confounded, but it is unlikely that $1 \mathrm{~kg}$ of mo- 
lasses would have a positive and $2 \mathrm{~kg}$ of molasses a great negative effect on the milk yield.

Only minor, though sometimes significant, differences in milk fatty acid composition were found between $\mathrm{Ba}$ and SBP supplements. Yields of individual fatty acids reflected the total fat yield. The lower proportion and yield of butyric acid on SBP than on Ba diets were related to lower concentration of plasma $\beta$-hydroxybutyrate (1.76 v. $2.30 \mathrm{mM})$. According to the review by MOORE and CHRISTIE (1981), about $40 \%$ of the butyric acid in milk is synthesized by condensation of two acetate molecules, while the remaining $60 \%$ appears to be derived from $\mathrm{C}_{4}$ components.

The Ba and SBP supplements had a similar effect on the proportion and total yield of $\mathrm{C}_{6}-\mathrm{C}_{14}$ fatty acids, suggesting that the availability of precursors, i.e. VFA, in the rumen was not affected by the type of supplement. An increase in the proportion of fatty acids of odd carbon number, especially of $\mathrm{C}_{15}$, on the SBP diet may reflect an increased synthesis of microbial lipids in the rumen. Mixed rumen bacteria and protozoa contain a high proportion of fatty acids of odd carbon number, both straight and branched chain (HARFOOT 1981). The higher proportion of $C_{15}$ with SBP cannot be explained by dietary origin, because unmolassed SBP contains only $0.13-$ $0.18 \%$ of digestible ether extract (KELLY 1983). Another primer to give with fatty acids with odd number of carbon atoms is propionate, which may be incompletely metabolized in the liver and enters the peripheral circulation with diets asssociated with high propionate production (ROOK and THOMAS 1983).

\section{Digestibility}

The similar OM digestibilities of the $\mathrm{Ba}$ and SBP diets agree with the results of MAYNE and GORDON (1984). However, THOMAS et al. (1986) reported a lower digestibilities of DM and gross energy for SBP diet. The lower crude protein digestibility with SBP may be due to the heating during the drying process, and in part to the higher proportion of ADF bound nitrogen in SBP than in cereal grains.

The lower digestibility of fibre components on barley diets is in agreement with many other studies comparing starch and fibre based supplements, and has been attributed to reduced cellulolysis in the rumen with high levels of starch (EL-SHAZly et al. 1961). The level of supplementation has been found to influence the effect of type of concentrate on fibre digestion (THOMAS et al. 1986): when the level barley was increased the digestibility of fibre decreased markedly, but very little when the level of SBP was increased.

The high digestibility of SBP fibre (BHATTACHARYA and SLEIMAN 1971) contributed all the difference in the digestibility of fibre components, and the digestibility of silage was unaffected by the type of supplement. This result is consistent with the findings in the nylon bag incubations in bulls given similar diets (HUHTANEN 1987). In contrast, ISTASSE et al. (1986) reported that a concentrate based on SBP did not affect the digestibility of $\mathrm{NH}_{3}$-treated straw, whereas Ba depressed the digestibility of straw from 0.559 to 0.393 in dairy cows. A similar difference in effect was observed with diets for sheep of 0.3 of $\mathrm{NH}_{3}$-treated straw and 0.7 of rolled $\mathrm{Ba}$ or SBP (FAHMY et al. 1984). The lower proportion of supplement $(0.43)$ in the present study may be one reason for this discrepancy. Also, the type of forage may be relevant to the extent of reduction in fibre digestion in the rumen when starch or fibre based supplements are fed. Thus, an increase in the proportion of $\mathrm{Ba}$ based concentrate from 0 to 0.6 in the diet of dairy cows reduced the degradability of $\mathrm{NH}_{3}$-treated straw more than that of grass silage (FAHMY and SUNSTøL 1985).

Inclusion of Mo in the $\mathrm{Ba}$ diet did not impair the digestibility of fibre or silage OM. Supplementation of silage diets with sucrose, however, depressed the cellulose digestibility in calves (ENGLAND and Gill 1985). Similarly, Mertens and Loften (1980) found that the addition of starch to forage based diets leads to a reduction in cellulolytic activity as 
a result of rapid starch fermentation in the rumen. The results of the present study indicate that sugars do not depress fibre digestion when they are used to replace starch rather than as a supplement in silage based diet. The same conclusion can be drawn from the replacement of SBP by Mo. At higher levels of supplementation or inclusion of molasses, however, the response may be different.

\section{Utilization of energy}

Calculations of energy utilization confirm the equal or slightly better productive value of SBP than of barley. Ignoring live weight change the efficiency was higher $(\mathrm{P}<0.05)$ with SBP diets, but including live weight change the difference did not reach statistical significance, mainly because of the great standard error in live weight change. According to Alderman et al. (1982) live weight change is a poor method of estimating changes in body energy; for cows in early lactation at zero energy balance they found a live weight change of $+0.42 \mathrm{~kg}$. According to ThомAs and Rook (1983), most changes in diets which enhance milk output without a concomitant increase in energy intake reflect a repartitioning of energy. However, analysis of blood metabolites (Miettinen and Huhtanen 1987) has not indicated any great difference in the partitioning of energy between the SBP and Ba diets. The difference in ME output and ME supply between SBP and Ba diets was +5.5 MJ per day greater on the SBP than on $\mathrm{Ba}$ diets, which is equivalent to $1.1 \mathrm{~kg}$ of $\mathrm{FCM}$ or $0.16 \mathrm{~kg}$ of live weight gain. Relative to the standard deviation of live weight change $(0.44$ $\mathrm{kg} / \mathrm{d}$ ) and of the difference between the observed ME supply and calculated ME output (14.6 MJ), this difference is small.

Certain assumptions were made in the calculation of energy utilization. A lactose content of $48 \mathrm{~g} / \mathrm{kg}$ milk was assumed for all diets in calculating the milk energy, in agreement with other studies where SBP and Ba have been compared. Likewise, a similar energy value of DOM and factor to convert DE to ME were used for all diets. Van Es (1971) observed a slightly higher energy value for DOM of barley than for DOM of SBP, probably due to the higher fat and lower sucrose content of barley. However, in the present study the lower fat content of SBP was balanced with rapeseed oil. No differences in the ratio $\mathrm{DE} / \mathrm{ME}$ were found between barley and SBP or when starch was replaced by sucrose in diets given to dairy cows (Van Es et al. 1971).

Similar small increases in the efficiency of use of ME for milk production were noted by Van der Honig and Wieman (1983) when starchy and fibrous concentrates were compared in a calorimetric study. Van Es et al. (1971) reported that $\mathrm{DE}$ of $\mathrm{Ba}$ and SBP was used with the same efficiency. TYrrel et al. (1973) found that a greater proportion of the increase in energy balance was in milk when SBP was added to diet than when corn was added. Similar changes in energy partition occur when the ratio forage to concentrate is increased.

From the calculations of energy utilization, it can be concluded that the lower milk yield with diets containing $2 \mathrm{~kg}$ of molasses was not entirely caused by a change in the efficiency of the use of ME. On Ba diet forage intake was decreased, and on SBP diet live weight gain tended to be increased. In an energy balance trial Van Es et al. (1971) did not notice differences in the utilization of DE when $8 \%$ sucrose in concentrate was replaced by $8 \%$ starch. In the present study, sugar content was higher, 108 and $118 \mathrm{~g} / \mathrm{kg} \mathrm{DM}$, for treatments $\mathrm{B}$ and $\mathrm{E}$, respectively.

\section{Digesta passage}

The model used to describe marker excretion accounted for an average $93 \%$ of the variance in faecal marker concentration, which is slightly less than found with a more sophisticated model by Dhanoa et al. (1985). The graphical procedure used here gave a poor fit for early values of marker excretion curves. However, there were no differences in TMRT 
when calculated as TMRT $=\mathrm{TT}+1 / k_{1}+1 / k_{2}$ or from the relative marker concentrationssampling interval according to ThiELEMANS et al. (1978). Similar values for TMRT have been reported with the grab sampling and total faeces collection methods, for both dairy cows (Hartnell and Satter 1979) and sheep (LiNDBERG 1985).

The values reported here for TMRT, PMRT of liquid phase and the intercept at zero intake are similar to those reported by Udén (1984). Hartnell and Satter (1979) report a value of $26-28 \mathrm{~h}$ for liquid TMRT. The present value of $37 \mathrm{~h}$ for TMRT for solids is low compared to the values of about $50 \mathrm{~h}$ reported by Hartnell and SATter (1979) and UdÉn (1984). In the present study, the residual mean retention time was considerably shorter than that reported by UDÉN (1984), but the pool mean retention time was only $2-3 \mathrm{~h}$ shorter. The discrepancy may be attributed to the different physical characteristics of the particulate marker. In the present study, the Cr-straw was ground to pass a $1.5-\mathrm{mm}$ screen so that particles were available for passage without further comminution. The effect of the production of small particles from the large particle pool due to chewing, rumination and microbial activity was not included in TMRT, and hence $k_{1}$ only reflects the turnover of the small particle pool. On the other hand, anything which alters the character of fibre or inhibits microbial activity would affect the rate of production of small particles and confound any analysis of the rate of passage from the reticulorumen (GROVUM 1984). In this regard $\mathrm{Cr}$-mordanted food would appear to be unacceptable. The significant period effect on particulate passage may result in part from the differences in volume weight of $\mathrm{Cr}$-straw between periods (EHLe et al. 1984).

\section{Conclusions}

In conclusion, the results show that SBP given on equal DM basis results in higher milk and protein yields than does barley. Because of the lower fat content on the SBP diet, FCM and milk fat yields were not affected. According to this study, the different sources of digestible energy were utilized with similar efficiency. Therefore, instead of regarding $1 \mathrm{~kg}$ of DM of SBP as equivalent to $0.87-0.90 \mathrm{~kg}$ of DM of barley in the Finnish Feed Tables (SALO et al. 1982), SBP should replace barley on equal DM basis in the feeding of dairy cows. At the level of supplementation used in the present study ( 0.43 of total DM), no effect can be expected on the silage DM intake or on the digestibility of silage when barley is replaced by SBP. Including high levels of molasses in $\mathrm{Ba}$ or SBP leads to a reduction in milk yield without any marked change in milk composition. The best production response was obtained with a low level of molasses given with a mixture of barley and SBP indicating a synergism from the fermentation of ingredients at different rates.

Acknowledgement. The author is grateful to Mrs. Hannele Ala-Seppälä, Mr. Kari Tahvanainen and Mr. Mikko Ranta for excellent technical assistance during the experiments, to Mr. Martti Himanen and his staff for taking care of the animals, and to Finn Sugar Ltd. for financial support and for providing sugar beet pulp and molasses. The analyses of milk fat and protein content by Valio Laboratories and milk fatty acids by the State Institute of Dairy Research are greatfully acknowledged.

\section{References}

Alderman, G., Broster, W.H., Strictland, M.J. \& Johnson, C.L. 1982. The estimation of the energy value of liveweight change in lactating dairy cows. Livest. Prod. Sci. 9: 665-673.

ARC. 1980. The Nutrient Requirements of Ruminants. Commonwealth Agricultural Bureaux. 351 p. London. Bhattacharya, A.N. \& Sleiman, F.T. 1971. Beet pulp as a grain replacement for dairy cows and sheep. J. 
Dairy Sci. 54: 89-94.

- \& Lubbadah, W.F. 1971. Feeding high levels of beet pulp in high concentrate dairy rations. J Dairy Sci. 54: 95-99.

Barker, S.B. \& Summerson, W.H. 1941. The colorimetric determination of lactic acid in biological material. J. Biol. Chem. 138: 535-554.

Bowman, R.L. \& Huber, J.T. 1967. Effect of dietary lactose on milk composition and rumen volatile fatty acids. J. Dairy Sci. 50: 579-581.

Broster, W.H., Sutton, S.D., Smith, T., Broster, V.J. \& BALCh, C.C. 1970. The effect of supplements of sucrose and of glucose monohydrate on the milk production and live weight of dairy cows. J. agric. Sci., Camb. 74: 217-225.

Chamberlain, D.G., Thomas, P.C., Wilson, W.D., KasSEM, M.E. \& Robertson, S. 1984. The influence of the type of carbohydrate in the supplementary concentrate on the utilization of silage diets for milk production. Proc. 7th Silage Conf. Queen's Univ., Belfast. (Ed. Gordon, F.J. \& Unsworth, E.F.). pp. 37-38.

CAstle, M.E. 1972. A comparative study of the feeding value of dried sugar-beet pulp for milk production. J. agric. Sci., Camb. 78: 371-377.

-, Gıl., M.S. \& WATSON, J.N. 1981. Silage and milk production: a comparison between barley and dried sugar beet pulp as silage supplement. Grass Forage Sci. 36: 319-324.

— \& WATSON, J.N. 1975. Silage and milk production: a comparison between barley and dried grass as supplements to silage high digestibility. J. Br. Grassld. Soc. 30: $217-222$.

Dhanoa, M.S., Siddons, R.C., France, J. \& Gale, D.L. 1985. A multicompartmental model to describe marker excretion patterns in ruminant faeces. Br. J. Nutr. 53: $663-671$

Ehle, F.R., Bas, F., Barno, B., Martin, R. \& Leone, F. 1984. Particulate rumen turnover rate measurement as influenced by density of passage marker. J. Dairy Sci. 67: 2910-2913.

El-Shazly, K., Dehority, B.A. \& Johnson, R.R. 1961. Effect of starch on the digestion of cellulose in vitro and in vivo by rumen microorganisms. J. Anim. Sci. 20: 268-273.

England, P. \& Gill, M. 1985. The effect of fish meal and sucrose supplementation on the voluntary intake of grass silage and live-weight gain of young cattle. Anim. Prod. 40: 259-265.

Es, A.J.H. van, Nıjkamp, H.J. \& Vogt, J.E. 1971. The net energy content of dried sugar-beet pulp and of sucrose when fed to lactating cows. Neth J. agric. Sci. 19: $48-56$.

FAнмy, S.T.M., \& LeE, N.H. \& ØrSkov, E.R. 1984. Digestion and utilization of straw. 2. Effect of different supplements on digestion of ammonia-treated straw. Anim. Prod. 38: 75-81.

— \& Sundstøl, F. 1985. The degradability of untreated and chemically treated barley straw and of grass silage as influenced by the ration composition. Z. Tierphysiol., Tierernähr. u. Futtermittelkde. 53: 34-42.

Flatt, W.P., Moe, P.W., Moore, L.A., Hooven, N.W., Lehmann, R.P., Ørskov, E.R. \& Hemken, R.W. 1969. Energy utilization by high producing dairy cow. Energy Metabolism of Farm Animals (Ed. Blaxter, K.L., Kielanowski, J. \& Thorbek, G.) EAAP Publ. No. 12. pp. $221-251$.

Forbes, J.M. 1980. Hormones and metabolites in the control of feed intake. In Digestive Physiology and Metabolism in Ruminants. (Ed. Ruckebush, Y \& Thivend, P.) pp. 145-159. MTP Press, Lancaster.

Goering, H.R. \& V Von Soest, P.J. 1970. Forage fiber analyses. Agriculture Handbook No. 379. United States Dept. of Agric. Washington.

Grovum, W.L. 1984. Integration of digestion and digesta kinetics with control of feed intake - a physiological framework for model of rumen function. Herbivore Nutrition in Subtropics and Tropics. (Ed. Gilchirst, F.M.C. \& Mackie, R.I.) pp. 244-268. The Science Press. Graighall.

— \& PhilıPS, D.G. 1973. Rate of passage studies in sheep. 5. Theoretical considerations based on a physical model and computer simulation. Br. J. Nutr. 30: 377-390.

— \& Williams, V.J. 1973. Rate of passage in sheep. 4. Passage of marker through alimentary tract and the biological relevances of rate-constants derived from changes in concentration of marker in faeces. $\mathrm{Br}$. J. Nutr. 30: 313-329.

Harfoot, C.G. 1981. Lipid metabolism in the rumen. Lipid Metabolism in Ruminant Animals. (Ed. Christie, W.W.) pp. 21-55. Pergamon Press.

Hartnell, G.F. \& Satter, L.D. 1979. Determination of rumen fill, retention time and ruminal turnover rates of ingesta at different stages of lactation of dairy cows. J. Anim. Sci. 48: 381-392.

Hemingway, R.G., Parkins, J.J. \& Fraser, J. 1986. Sugar beet pulp products for dairy cows. Anim. Feed Sci. Technol. 15: 123-127.

Honing, Y. Van der \& Wieman, B.J. IVVO-Report 145. Institute for Livestock Feeding and Nutrition Research: Lelystad. (ref. Steg, A, Honing, Y. Van der \& Visser, H De).

Huhtanen, P. 1987. The effects of barley, unmolassed sugar beet pulp and molasses supplements on organic matter, nitrogen and fibre digestion in the rumen of cattle given silage diet. Submitted.

HuidA, L. 1973. Quantitative determination of volatile fatty acids by gasliquid chromatography. J. Scient. Agric. Soc. Finl. 45: 483-488.

Istasse, L., Reid, G.W., Tait, C.A.G. \& Ørskov, E.R. 1986. Concentrates for dairy cattle: effects on feeding method, proportion in diet and type. Anim. Feed Sci. \& Technol. 15: 167-182.

KAUfMANN, W. 1976. Influence of the composition of the 
ration and the feeding frequency on $\mathrm{pH}$-regulation in the rumen and on the feed intake in ruminants. Livest. Prod. Sci. 3: 103-114.

Lees, J.A., Garnsworthy, P.C. \& Oldham, J.D. 1982: The response of dairy cows in early lactation to supplements of protein given with rations designed to promote different patterns of rumen fermentation. Forage Protein in Animal Production. Occasional Publ. No. 6. Brit. Soc. Anim. Prod. (Ed. Thomson, D.J., Beever, D.E. \& Gunn, R.G.) pp. 157-159.

Kelly, P. 1983. Sugar beet pulp - a review. Anim. Feed Sci. \& Technol. 8: 1-18.

Krohn, C.C. \& Andersen, P.E. 1979. Ratios with beet or barley fed separately or in complete ration for dairy cows. Beretnig fra Statens Husdyrbrugsforsøg. 480.

LindBerg, J.E. 1985. Retention of chromium-labelled feed particles and of water in gut of sheep given hay and concentrate at maintenance. Br. J. Nutr. 53: 559567.

Lofgreen, G.P. \& Otagakı, K.K. 1960. The net energy of blackstrap molasses for lactating dairy cows. J. Dairy Sci. 43: 220-230.

Madsen, J. \& Hvelplund, T. 1985. Protein degradation in the rumen. Acta. Agric. Scand. Suppl. 25: 103-124.

MAFF (Ministry of Agriculture, Fisheries and Food). 1975. Energy allowances and feeding systems for ruminants. Technical Bulletin 33. 79 p. London.

MAYne, C.S. \& Gordon, F.J. 1984. The effect of type of concentrate and level of concentrate feeding on milk production. Anim. Prod. 39: 65-76.

McCullough, H. 1967. The determination of ammonia in whole blood by direct colorimetric method. Clin. Chem. Acta 17: 297-309.

Mertens, D.R. \& Loften, J.R. 1980. The effect of starch on forage digestion kinetics in vitro. J. Dairy Sci. 63: 1437-1446.

MEıs, J.A.C. 1986. Concentrate supplementation of grazing dairy cows. 2 . Effect of concentrate composition on herbage intake and milk production. Grass Forage Sci. 41: 229-235.

Miettinen, H. \& Huhtanen, P. 1987. The effect of the type of supplement on blood metabolites in dairy cows given grass silage ad libitum. Unpublished.

Moe, P.W., Flatt, W.P. \& Tyrrel, H.F. 1972. Net energy values of feed for lactation. J. Dairy Sci. 55: 945-958.

MoOre, J.H. Christie, W.W. 1981. Lipid metabolism in the mammary gland of ruminant animals. Lipid Metabolism in Ruminant Animals. (Ed. Christie, W.W.) pp. 227-277. Pergamon Press, Lancaster.

Murphy, J.J. 1985. Effect of feeding sodium bicarbonate in the concentrate or beet pulp on milk yield and composition in cows after turnout to pasture in spring. Ir. J. agric. Res. 24: 143-149.

Murphy, M., Huhtanen, P. \& Ala-Seppälã, H. 1986. The effect of different supplements on rumen and total tract digestion in cows given grass silage. Unpublished.
Nelson, N. 1944. A photometric adaptation of Somogyi method for the determination of glucose. J. Biol. Chem. 153: $375-380$.

Parkins, J.J., Hemingway, R.G. \& Fraser, J. 1986. A note on dried molassed sugar beet pulp and unmolassed pressed sugar beet pulp as comparative foods for dairy cows. Anim. Prod. 43: 351-354.

Porter, M.G., Patterson, D.C., Steen, R.W. \& GorDON, F.J. 1984. Determination of dry matter and gross energy of grass silage. Proc. 7th Silage Conf. Queen's Univ. Belfast. (Ed. Gordon, F.J. \& Unsworth, E.F.). pp. 89-90.

Robertson, J.B. \& VAn Soest, P.J. 1977. Dietary fiber estimation in concentrate feedstuffs. 69th meeting of Amer. Soc. of Anim. Sci. 639.

Rоок, J.A.F. \& Tномаs, P.C. 1983. Milk secretion and its nutritional regulation. Nutritional Physiology of Farm Animals. (Ed. Thomas, P.C. \& Rook, J.A.F.) pp. 315-368.

SAlo, M-L. \& SAlmi, M. 1968. The determination of starch by amyloglucosidase method. J. Scient. Agric: Soc. Finl. 40: 38-45.

-, TUORI, M. \& KIISKInEN, T. 1982. Rehutaulukot ja ruokintanormit. 70 p. Helsinki.

Steg, A., Honig, Y. Van der \& Visser, H. De. 1985. Effect of fibre in compound feed on the performance of ruminants. Recent Advances in Animal Nutrition. (Ed. Haresign, W. \& Cole, D.J.A.) pp. 113-129. Butterworths.

SutTon, J.D. 1980. Influence on nutritional factors on the yield and content of milk fat: dietary components other than fat. Bull. Int. Dairy Fed. 125: 126-134.

- 1984. Feeding and milk fat production. Milk Compositional Quality and its Importance in Future Markets. Occasional Publ. No. 9. Br. Soc. Anim. Prod (Ed. Castle, M. \& Gunn, R.G.) pp. 43-52.

-, BINes, J.A., NAPPer, D.J., WII Kes, J.M. \& Schul. LER, E. 1984. Form of carbohydrates in dairy concentrates. Report of National Institute for Research in Dairying. p. 74.

—, BıNES, S.A. \& NAPPER, D.J. 1985. Comparison of starchy and fibrous concentrates for lactating dairy cows. Anim. Prod. 40: 533. (Abstr).

Thielemans, M.R., Fracois, E., Bodart, C. \& Thewis, A. 1978. Measurement of gastrointestinal transit in pigs by radiolanthanide. Comparison with sheep. Ann. Biol. Anim. Biochem. \& Biophys. 18: 237-247.

Thomas, C., Aston, K., Daley, S.R. \& Bass, J. 1986. Milk production from silage. 4 . The effect of the composition of the supplement. Anim. Prod. 42: 315-325.

Thomas, P.C. \& Chamberlain, D.G. 1984. Manipulation of milk composition to meet market needs. Recent Advances in Animal Nutrition 1984. (Ed. Haresign, W. \& Cole, D.J.A.). pp. 219-243. Butterworths.

— \& Rоoк, J.A.F. 1983. Milk production. Nutritional Physiology of Farm Animals. (Ed. Thomas, P.C. \& Rook, J.A.F.) pp. 558-622. Longman. 
-, Kelly, N.C., Chamberlain, D.G. \& Chalmers, J.S. 1980. Some aspects of energy and protein utilization in ruminants given grass silage. Energy Metabolism. (Ed. Mount, L.E.) pp. 357-362. Butterworths.

Tyrrel, H.F., Moe, P.W. \& Bull, L.S. 1973. Energy value of cracked corn and dried beet pulp. J. Dairy Sci. 56: 1384-1385. (Abstr).

— \& ReId, J.T. 1965. Prediction of energy value of cow's milk. J. Dairy Sci. 48: 1215-1223.

UDEN, P. 1984. Digestibility and digesta retention in dairy cows receiving hay or silage at varying concentrate levels. Anim. Feed Sci. Technol. 11: 279-291.

-, COlucCI, P.E. \& VAN SOEST, P.J. 1980. Investigation of chromium, cerium and cobalt as markers in digesta. Rate of passage studies. J. Sci. Food Agric. 31: 625632.

\section{SELOSTUS}

\section{Ohran, juurikasleikkeen ja melassin vaikutus maidontuotantoon, rehun sulavuuteen sekä rehun viipymisaikaan ja virtausnopeuteen vapaalla säilörehuruokinnalla}

\section{Pekka Huhtanen \\ Helsingin yliopisto, kotieläintieteen laitos, $00710 \mathrm{Helsinki}$}

Tutkimuksessa selvitettiin viiden erilaisen väkirehun vaikutusta maidontuotantoon, rehun sulavuuteen sekä viipymisaikaan ja virtausnopeuteen vapaalla säilörehuruokinnalla. Koe-eläimină oli $10 \mathrm{Ay}$-lehmaaă, joista puolet oli ensikkoja. Koe tehtiin kaksinkertaisena $5 \times 5$ latinalaisena neliönä. Vaakirehut koostuivat seuraavista raaka-aineista (g/kg kuiva-ainetta (ka)): (A) ohra $1000 \mathrm{~g}$, (B) ohra $667 \mathrm{~g}$ ja melassia $326 \mathrm{~g}$, (C) ohra $417 \mathrm{~g}$, leike $410 \mathrm{~g}$ ja melassi $163 \mathrm{~g}$; (D) leike $983 \mathrm{~g}$ sekä (E) leike $656 \mathrm{~g}$ ja melassi $326 \mathrm{~g}$. Leikkeen ja melassin ohraa alempi raakarasvapitoisuus tảydennettiin rypsiöljyllä. Eläimet saivat näitä văkirehuja koko kokeen ajan 6 kg ka/pv, minkä lisäksi annettiin $1 \mathrm{~kg}$ rypsirouhetta ja $250 \mathrm{~g}$ kivennäisseosta päivässä.

Ohra- ja leikedieettien vălillă ei ollut eroa săilörehun syönnissă, mutta melassidieeteillä (BE) säilörehun ja samalla kokonaiskuiva-aineen syönti vähenivät. Leikeruokinnoilla (DE) maitotuotos oli $1.1 \mathrm{~kg}(\mathrm{P}<0.01)$ ja valkuaistuotos $32 \mathrm{~g}(\mathrm{P}<0.05)$ korkeampi kuin vastaavat tuotokset ohraruokinnoilla (AB). Sen sijaan maidon rasvapitoisuus oli leikedieeteillă merkitsevästi $(\mathrm{P}<0.001)$ alempi kuin ohradieeteillä $(46.0$ vs. $49.1 \mathrm{~g} / \mathrm{kg}$ ) ja siten rasvatuotoksessa ja rasvakorjatussa (RKM) maitotuotoksessa ei ollut eroa näiden ruokintojen vălillä. Ohran tai leikkeen
Van Keulen, J. \& Young, B.A. 1977. Evaluation of acidinsoluble ash as a natural marker for digestibility studies. J. Anim. Sci. 44: 282-287.

Visser, H., De \& Groot, A.A.M., De. 1981. The influence of starch and sugar content of concentrates on feed intake, rumen fluid, production and composition of milk. Metabolic Disorders in Farm Animals (Ed. Giesecke, D., Dirksen, G \& Stangassinger, M) pp. 41-48. Veterinary Institute, Univ. of Munich.

Williams, C.H., David, D.J. \& Rilsmaa, O. 1962. The determination of chronic oxide in faeces samples by atomic absorption spectrometry. J. agric. Sci., Camb. 59: $381-385$.

Ms received April 27, 1987 korvaaminen melassilla alensi maito- $(\mathrm{P}<0.001)$, RKM-, rasva- ja valkuaistuotosta $(\mathrm{P}<0.01)$, mutta maidon koostumukseen melassilla ei ollut vaikutusta. Parhaimman tuotoksen antoi kuitenkin monipuolinen rehuyhdistelmä (C), joka sisälsi sekä ohraa, leikettă ettă melassia. Ero oli merkitsevă maito-, RKM- ja rasvatuotoksessa $(\mathrm{P}<0.05)$ sekå valkuaistuotoksessa $(\mathrm{P}<0.01)$ neljän muun dieetin keskiarvoon nähden.

Dieettien vaikutus rehun sulavuuteen mäăritettiin viidellă lehmällă käyttảen suolahappoon liukenematonta tuhkaa merkkiaineena. Dieettien orgaanisen aineen sulavuus oli keskimäärin 0.743 , eikă dieettien vălillă ollut merkitseviä eroja. Raakavalkuaisen sulavuus oli ohradieeteillă parempi $(\mathrm{P}<0.001)$ ja erilaisten kuitufraktioiden sulavuus huonompi $(\mathrm{P}<0.001)$ kuin leikedieeteillä. Laskettaessa säilörehun sulavuus erotuksella dieettien vălillă ei kuitenkaan voitu todeta eroja.

Muuntokelpoisen energian hyväksikäyttő oli hieman parempi leikedieeteillä kuin ohradieeteillă. Huolimatta alentuneesta maidontuotannosta energian hyväksikäyttö ei melassidieeteillă ollut huonompi, vaan huonompaan tuotokseen oli syynä pääasiassa alentunut karkearehun syönti ja osaksi suurempi elopainon lisảys.

Nestefaasin ja partikkeleiden virtausnopeus määritet- 
tiin käyttämällă merkkiaineina CoEDTA:ta ja $\mathrm{Cr}$-merkittyă olkea. Nesteen keskimääräinen viipymisaika vaihteli 18.0:sta 19.9 tuntiin ja partikkeleiden 36.8:sta 37.7 tuntiin dieetistä riippumatta. Partikkeleiden virtausnopeus pötsistă vaihteli vălillă $0.045-0.048$ ja nesteen $0.096-$
0.104 , eikä dieettien vălillă ollut merkitseviä eroja.

Tämän sekä ulkomaisten tutkimusten perusteella leikkeen ja ohran kuiva-aineen tuotantovaikutus lypsylehmillä on sama huolimatta $12-15 \%$ :n erosta niiden ry-arvossa rehutaulukoissa. 